\title{
蛋白質の選択的な化学修飾法における 最近の進歩
}

\author{
北 川常廣* \\ Recent Progress in the Methods for Selective Modification \\ of Proteins.
}

Tsunehiro KITAGAWA*

\begin{abstract}
Methods for preparations of protein-protein and protein-hapten conjugates are reviewed from the view point of selective formation of the conjugates. The methods are classified into four types depending upon the chemical structures of the modifiers of proteins. The specific methods applied for mono-functional haptens having a carboxylic acid, amino or thiol group and non-specific ones used for polyfunctional modifiers in aids of homo-bifunctional reagents. The selective method utilizing the structural specificities of the protein and also the newly developed selective methods using hetero-bifunctional cross-linkers such as the maleimide succinimidyl ester type are discussed.
\end{abstract}

\section{はじめに}

蛋白質一蛋白質複合体の作製法 ${ }^{1 \sim 5)}$ は, 種々の臨床検 查法や, 生化学的, 薬理学的に有用な物質の調製法とし て, 近年ますます重要になってきた。蛋白質は基本的に 多種類のアミノ酸で構成される高分子化合物で, アミノ 基, カルボン酸基, 水酸基, チオール基やフェノール基 等, 数多くの官能基を有する。しかし生理機能を示す蛋 白質は失活しやすいので, 選択的に蛋白質一蛋白質の結 合反応を行い, しかもこの際に個々の蛋白質の生理機能 を保持させるのは容易でなかった。

蛋白質一蛋白質の複合反応とともに, 低分子のホルモ ンや, 薬剤等で蛋白質を化学修飾する反応は薬物の抗原 作製法 ${ }^{5,6)}$ や酵素標識法 ${ }^{7 ~ 12)}$ ，あるいはアフィニティーク ロマト法 ${ }^{3)}$ 等にも重要である。これらの反応も基本的に 蛋白質の選択的な化学修飾法を応用して蛋白質複合体を 調製するので, 蛋白質の選択的な化学修飾法の観点から 最近の進歩を紹介する。

\section{2. 蛋白質の化学修飾反応に要求される条件}

蛋白質の不安定な生理機能の失活をさけるために, 化 学修飾反応は次の 5 条件を満たす反応であることが必要

\footnotetext{
* 長崎大学薬学部薬学科

* Faculty of Pharmaceutical Sciences, Nagasaki University
}

()
である7 ${ }^{7)}$ 。従ってこの 5 条件を基準にして, 蛋白質の化 学修飾法の進歩を取り挙げる。

I. 蛋白質が所持する，またはIII V V 条件下に導入 できる官能基を利用する反応であること。

II. 選択的に反応が進行して副反応が起きにくいこと。

III. ほぼ中性の水溶液中で反応すること。

IV. 室温以下の温度で短時間に反応が完結すること。

V. 生成した結合は安定であること。

この 5 条件を満たす蛋白質の化学修飾法は, まずアフ ィニティークロマト法の技術で必要な酵素等の固定化法 が研究され ${ }^{3)}$, さらに免疫測定法の分野で特に酵素標識 法 $^{5 \sim 12)}$ の研究過程で発展してきた。

\section{3. 蛋白質の化学修飾に用いられる官能基}

蛋白質の分子中にあり化学修飾に利用される官能 基 $^{13,14)}$ と，それに対応するアミノ酸を表 1 に示す。

表 1 蛋白質分子中の官能基

\begin{tabular}{l|l}
\hline \multicolumn{1}{c|}{ 官能 基 } & 含有アミノ酸 \\
\hline アミノ基, イミノ基 & Lys, Arg, His, Try \\
カルボン酸基 & Asp, Glu \\
水酸基 & Ser, Thr, Tyr \\
フェノール基 & Tyr \\
芳香環 & Tyr, Phe, Try, His \\
チオール基 & Cys \\
\hline
\end{tabular}

これらの官能基以外に，蛋白質を構成する糖鎖 も後述 
する如く化学修飾反応に重用される。

\section{4. 簡単な構造の化合物との蛋白質複合体 の作製法}

低分子化合物であるハプテンの抗原作製法 $\left.{ }^{5,6}, 15 \sim 17\right) を$ 中心としてその作製法が研究された。単一の官能基, 力 ルボン酸基, 水酸基，アミノ基等のみを持つ低分子化合 物は, 以下の反応を利用してほぼ選択的に蛋白質の化学 修飾できる。

4. 1. カルボン酸基 ペプチド合成法 ${ }^{18)} に$ 常用され る活性化法を用いて蛋白質のアミノ基に選択的に結合で きる。主として次の 2 法が用いられる。

4. 1. 1. 酸無水物法 ${ }^{19 \sim 23)}$ アルキルクロロホルメート を用いる水溶液反応が主である。

$$
\begin{aligned}
& \mathrm{R}-\mathrm{COOH}+\mathrm{R}^{\prime}-\mathrm{OC}-\mathrm{Cl} \longrightarrow \\
& \mathrm{O}=\overbrace{\mathrm{O}-\mathrm{R}^{\prime}}^{\stackrel{\mathrm{I}}{\mathrm{C}}-\mathrm{R}} \stackrel{\text { Protein }-\mathrm{NH}_{2}}{\longrightarrow} \text { Protein }-\mathrm{NH}-\stackrel{\mathrm{O}}{\mathrm{C}}-\mathrm{R}
\end{aligned}
$$

4. 1. 2. $\boldsymbol{N}$-ヒドロキシサクシイミド法 ${ }^{24 ~ 27) ~}$ 本基は 活性エステルの中で最も水溶性の構造を有し, 多用され る。

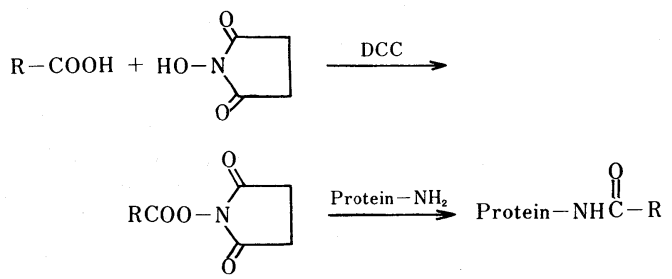

\section{2. アミノ基のみを有する化合物}

4. 2. 1. 芳香族アミノ基 酸性水溶液中でジアゾ化後 アルカリ性でジアゾカップリングする ${ }^{28 \sim 30) 。 ~}$

$$
\begin{aligned}
& \mathrm{Ar}-\mathrm{NH}_{2} \underset{\mathrm{HCl}}{\stackrel{\mathrm{NaNO}_{2}}{\longrightarrow}} \mathrm{Ar}-\mathrm{N}_{2}^{+} \mathrm{Cl}^{-} \\
& \stackrel{\operatorname{Protein}(-\mathrm{Tyr}-)}{\longrightarrow}
\end{aligned}
$$

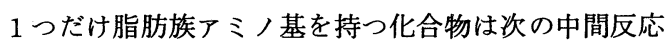

を経てジァゾカップリング反応が応用された ${ }^{30 ~ 31) 。 ~}$

$$
\begin{aligned}
& \mathrm{R}-\mathrm{NH}_{2}+\mathrm{Cl}-\stackrel{\mathrm{O}}{\mathrm{C}} \longrightarrow-\mathrm{NO}_{2} \longrightarrow
\end{aligned}
$$

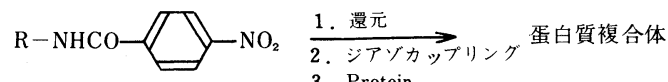

以上これらの反応はいずれも蛋白修飾反応の 5 条件を 完全にはみたしていないので, 各方法に対応した実験条件 を選ぶ必要はあるが, 蛋白質の重合反応が起らない点で, 選択的な蛋白質の修飾反応に分類できる。

\section{5. 同反応性 2 価試薬を用いる蛋白質の化 学修飾反応}

蛋白質一蛋白質の複合反応には，同じ官能基間を結合 する, 種々の同反応性 2 価試薬類 (homo-bifunctional reagents) が用いられてきた ${ }^{1,2)}$ 。

通常蛋白質は分子内に同じ官能基を多数持つので, こ の場合には一般式で示すと（式 1 ）に示す複雑な組成の 複合体を与える ${ }^{7,32)}$ 。

$$
\begin{aligned}
& \text { Protein I + X-R }-\mathrm{X}+\text { Protein II } \\
& \quad \longrightarrow(\text { Protein } \mathrm{I})_{\mathrm{x}}-(\mathrm{R})_{\mathrm{y}}-(\text { Protein II })_{\mathrm{z}} \quad(1) \\
& \mathrm{X}-\mathrm{R}-\mathrm{X} \text { : 同反応性 } 2 \text { 価試薬 } ; \mathrm{x}, \mathrm{y}, \text { または } \mathrm{z}=0,1,2,3,4 \cdots
\end{aligned}
$$

従って, 目的の複合体 (Ia; $\mathrm{x}=\mathrm{y}=\mathrm{z}=1$ ) を選択的に 生成する, あるいは複雑な混合生成物から単離するのは 容易でない欠点を有するが，実用上便利なので種々の方

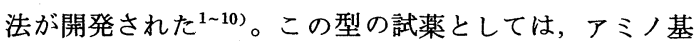
同志を結合する型と, チオール基間を縮合する型の試 薬が知られている。

5. 1. アミノ基用同反応性 2 価試薬 この型の試薬類 は主反応のアミノ基以外にチオール基や水酸基とも反応 する。通常アルカリ性下で反応するので条件 II 〜 IV を満 たし難い。

\section{1. 1. ジハロゲン試薬}

一般式 $\mathrm{X}-\mathrm{R}-\mathrm{X}$<smiles>[R]CC(=O)Nc1ccc(N=Nc2ccc(NC(=O)CO)cc2C(=O)O)c(C(=O)O)c1</smiles> 
<smiles>Cc1cc(C)c([N+](=O)[O-])cc1[N+](=O)[O-]</smiles>

$$
: \mathrm{X}=\mathrm{F}^{36.37)}
$$<smiles>CCCCOc1nc(Cl)nc(Cl)n1</smiles><smiles>CCCNc1nc(Cl)nc(OCC)n1</smiles>

トリアジンの塩化物は酵素のアフィニティーカラム作 製に用いられた ${ }^{38,39) 。 ~}$

5. 1. 2. ジイソシアネート, ジチオイソシアネート型 試薬 一般式 $\mathrm{O}=\mathrm{C}=\mathrm{N}-\mathrm{R}-\mathrm{N}=\mathrm{C}=\mathrm{O}, \mathrm{S}=\mathrm{C}=\mathrm{N}-\mathrm{R}$ $-\mathrm{N}=\mathrm{C}=\mathrm{S}$<smiles>Cc1ccccc1CN=C=O</smiles><smiles>O=C=NCc1cccc(CN=C=O)c1</smiles><smiles>Cc1ccc(N=C=S)cc1N=C=O</smiles>

とともに，水溶性の<smiles>O=C=Nc1ccc(N=Nc2ccc(N=C=O)cc2C(=O)O)c(C(=O)O)c1</smiles>

などが市販品で入手可能であるので，良く利用されてい $3^{40,41)}$ 。

5. 1. 3. ジアルキル化試薬

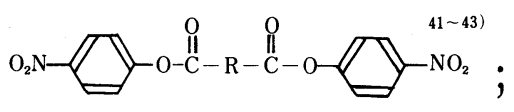<smiles>Cc1ccc([Se][Cl+3](Cl)(Cl)Cl)cc1[Se]Cl</smiles>

などの構造の試薬が報告されている。

5. 1. 4. ジアルデヒド類 ; グルタルアルデヒド法 最 も多用されるグルタルアルデヒドはアルデヒド基を $2 つ$ 持つが水溶液の市販品では, 単独分子でなく分子間で縮 合して,アルデヒド基に共役二重結合をいくつも持った 重合体として存在し，アミノ基はこの二重結合に付加反 応をする ${ }^{45)}$ 。緩和な条件下に反応が進行し, 蛋白質の化 学修飾条件吕 V を満足する方法で, 初为蛋白のアフィ ニティーカラム作製に用いられた $\left.{ }^{46} 48\right)$ が次いで醳素の固 定化 ${ }^{49)}$ や標識法 ${ }^{50 ~ 52)}$ に用いられた。反応に選択性がない 欠点を有するが，安価なので抗原や抗体の固定化に用い られている ${ }^{53 \sim 54)}$ 。

5. 2. チオール基用試薬; ジマレイミド法 チオー ル基は緩和な条件下に迅速かつ選択的にマレイミド基の 二重結合に付加反応をする ${ }^{55 \sim 58)}$ 。この特性を応用する以 下の構造の試薬類が市販されている。

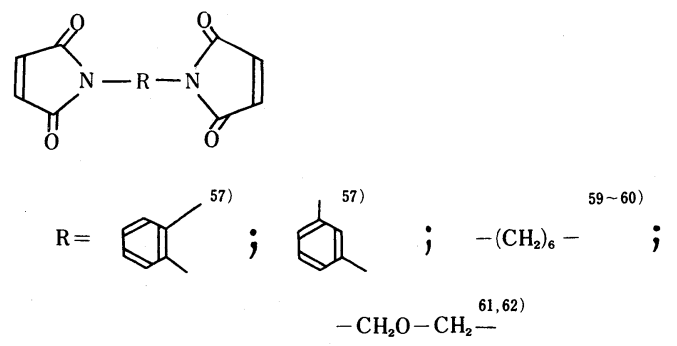
チオール基は空気酸化でジスルフィド結合に変りやす
Protein $-\mathrm{NH}_{2}$ $\stackrel{\substack{\mathrm{NH}_{2} \\ \mathrm{HS}-\mathrm{CH}_{2} \mathrm{CH}_{2}-\stackrel{\mathrm{C}}{\mathrm{C}}-\mathrm{OCH}_{3}}}{\longrightarrow}$ Protein $-\mathrm{NH}-\stackrel{\mathrm{NH}}{\mathrm{CH}}-\mathrm{CH}_{2}-\mathrm{CH}_{2}-\mathrm{SH}^{65)}$<smiles>COC1CC2OC(=O)C12</smiles>

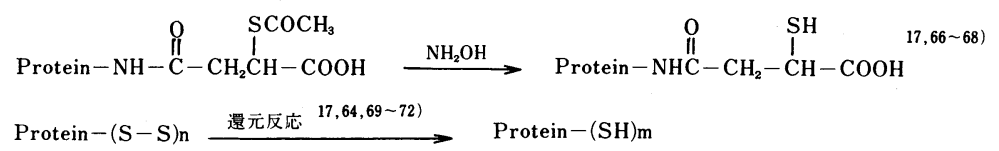


く ${ }^{63,64)}$ 遊離型で存在しにくい。チオール基は前記の緩和 な条件下の反応で蛋白質に容易に導入できる ${ }^{64 ~ 72) 。 ~}$

$\beta$-ガラクトシダーゼは遊離のチオール基を有し, こ のチオールは酵素活性に関与しないので加藤ら ${ }^{67)}$ はイン スリンに導入したチオール基を，o-フェニレンジマレ イミドを介して $\beta$-ガラクトシダーゼと結合するのに成功 し, さらに家鬼 IgG の Fab フラグメントも同様に酵素 標識に成功した ${ }^{72)}$ 。

\section{6. 糖鎖を反応に利用した選択的な蛋白質修飾 法 : 過ヨウ素酸酸化法 ${ }^{73 \sim 76)}$}

特殊な蛋白質では，含有する糖鎖を過ヨウ素酸酸化し て選択的にジアルデヒドに開裂し，ジアルデヒドは緩和 な条件下に水溶液中でアミノ基と結合できる。西洋わさ びのパーオキシダーゼは構成糖を有し, さらにアミノ基 を保護しても失活しないので，まずアミノ基をジニトロ ベンゼンで保護後に糖を開裂して, 生じたジアルデヒド を抗体や抗原等の（蛋白質の）アミノ基に結合し, 生じ たシッフ塩基を還元安定化する方法で，パーオキシダー ゼの構造特異性を巧みに応用した選択的なパーオキシダ 一ゼの標識法が開発された ${ }^{76,77) 。 ~}$
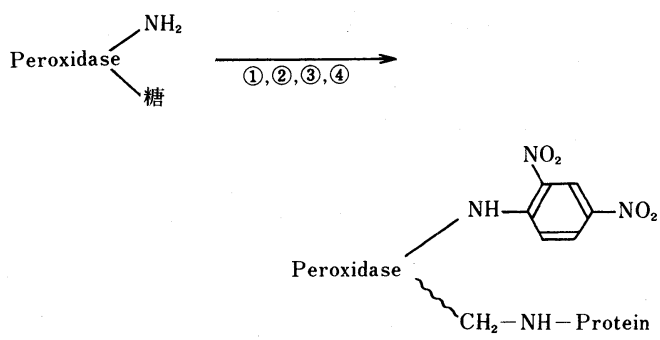

(1)<smiles>O=[N+]([O-])c1ccc(F)c([N+](=O)[O-])c1</smiles>
白質のアミノ基とジアルデヒドの反応; (4) $\mathrm{NaBH}_{4}$ によ る還元反応。

本法で作製された酵素標識抗体や抗原は酵素免疫測定 法 $^{7 \sim 12)}$ や組識免疫法 ${ }^{76 \sim 78)}$ に多用されている。

\section{7. 異反応性 2 価試薬 (hetero-bifunctional} reagents) による選択的な蛋白修飾法

7. 1. 選択的な蛋白修飾試薬の開発 1976年に筆者 らは異反応性 2 価試薬による選択的な蛋白修飾法を開発 した ${ }^{79)}$ 。蛋白修飾反応を選択的に進行させるために，第 1 反応は蛋白 I と反応し, 第 2 反応は蛋白 II とのみ反応 して蛋白 I とは反応しない型式である。
Protein $\mathrm{I}+\mathrm{X}-\mathrm{R}-\mathrm{Y} \longrightarrow$ Protein $\mathrm{I}-\mathrm{R}-\mathrm{Y}$

$\stackrel{+ \text { Protein II }}{\longrightarrow}($ Protein I) $-\mathrm{R}-($ Protein II $)$

この際に用いる両反応は, 前述の蛋白修飾条件 I と III 〜Vを満たす必要があり, さらに条件II むできる限り満 たす反応を用いた。第 1 反応には $N$-ヒドロキシサクシ イミド法（4.1. 2. 参照）を応用した。本法はペプチド合 成法として開発された ${ }^{24)}$ が，筆者らはいち早くその親水 性の構造に着目し, 水溶液反応の応用研究を行ってバイ オマイシン (VM) のアシル化に成功して分子式を決定 し ${ }^{25)}$ ，さらに構造決定 ${ }^{80)} に も$ 応用できた。さらにこの際 アシル化剂のモル数を制限すれば選択的に二つのアミノ 基の一方がアシル化できて ${ }^{26,81)}$ ，条件 II をかなり満足す ることを知った。従ってこの反応を反応 1 に用いること にした。第 2 反応にはマレイミド基（5.2.参照）を選び 異反応性 2 価試薬 $N-(m$-マレイミドベンゾイルオキシ) サクシイミド(MBS)を開発した ${ }^{23,79) 。 ~}$

7. 2. 新しい酵素標識法 異反応性 2 価試薬, MBS を用いると簡単な二段階反応でインスリンを $\beta$-ガラクト シダーゼで標識できた ${ }^{79,82)}$ 。この際の結合反応は蛋白修 飾法として必要な 5 条件をほぼ満足する。その結果 MBS 法を用いると低分子の $\mathrm{VM}^{23)}$ やアンジオテンシン $\mathrm{I}^{83)}$, ブラジキニン ${ }^{40)}$ からインスリン ${ }^{79)}$ やさらに高分子のヒト 胎盤性ゴナドトロピン ${ }^{84)}$ や IgG 類 ${ }^{8,54,85)}$ まで簡単に酵素 標識ができて，それぞれの高感度の酵素免疫測定法 (EIA) が開発できた。

Insulin $-\mathrm{NH}_{2}$

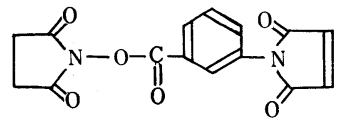

Incubate $30^{\circ} \mathrm{C}, 30^{\prime}$, In phosphate Buffer pH 7.0 Add $1 \mathrm{M}$ Citrate Buffer pH 5.0

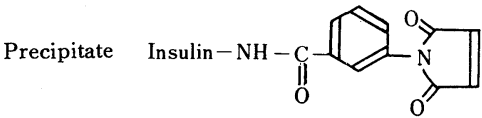

Estimation of Maleimide Residues MBSAcylated Insulin $+\mathrm{HS}-\boldsymbol{\beta}-\mathbf{D}-\mathrm{Galactosidase}$ Incubate $30^{\circ} \mathrm{C} 2 \mathrm{hr}$ in Phosphate Buffer $\mathrm{pH} 7.0$

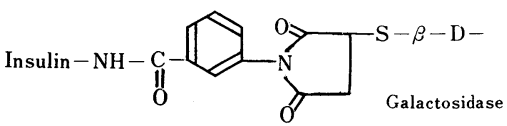

Chromatography on Sepharose 6 B Column

Fig. 1 Preparation of insulin- $\beta-\mathrm{D}$-galactosidase conjugate. 


\section{3. MBS 型試薬の構造と反応性, 安定性の相関関} 係 MBS 型架橋剂 10 種類について, 活性エステルの 反応性とマレイミド基の安定性が検討された ${ }^{15,32,86) 。}$

図 2 は使用した架橋剤の構造式を示す。表 2 は各試薬 $1 \mu$ モルをアミノ酸のリジン(Lys) とロイシン (Leu) そ れぞれ $1 \mu$ モルに $0.05 \mathrm{M}$ リン酸緩衝液 $(\mathrm{pH} 7.0,7.5,8.0)$ 中で $25^{\circ} \mathrm{C} ， 20$ 分間反応した時のアシル化收率を示す。

表 3 は各試薬 $1 \mathrm{mM}$ 濃度溶液を各緩衝液 ( $\mathrm{pH} 5.0,6.0$, $7.0,8.0)$ 中で $30^{\circ} \mathrm{C}, 30$ 分間および $\mathrm{pH} 7.5$ で 20 分間イ ンキュベート後のマレイミド基の分解率を示す。

芳香族の架橋剂は構造の差が活性エステルの反応性と マレイミド基の安定性に大きく影響した。すなわち $o-$ 型 (Ia), $m$-型 (Ib) と $p$-型 (Ic) では $m$-型が最も活性

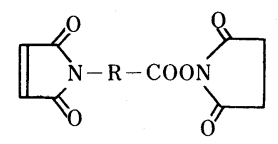

(Y)

(X)
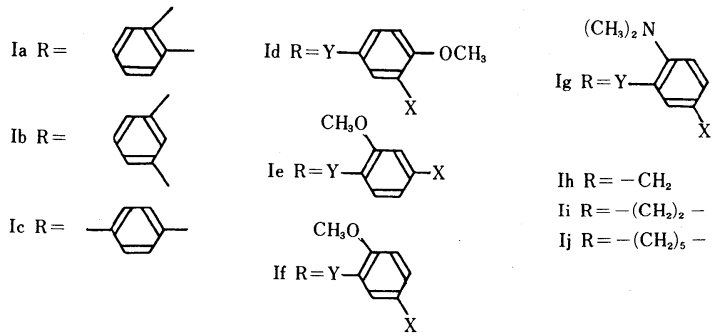

Ih $\mathrm{R}=-\mathrm{CH}_{2}$ Ii $\mathrm{R}=-\left(\mathrm{CH}_{2}\right)_{2}-$ Ij $\mathrm{R}=-\left(\mathrm{CH}_{2}\right)_{5}-$

Fig. 2 Chemical structures of the hetero-bifunctional cross-linkers used.

Table 2 Acylation percents of the hetero-bifunctional cross-linkers with leucine and lysine in 0.05 $\mathrm{M}$ phosphate buffers, $\mathrm{pH} 7.0,7.5$ and 8.0, at $30^{\circ} \mathrm{C}$ for 20 minutes.

\begin{tabular}{c|c|c|c|c|c|c}
\hline \multirow{2}{*}{} & \multicolumn{2}{|c|}{$\mathrm{pH} 7.0$} & \multicolumn{2}{c|}{$\mathrm{pH} 7.5$} & \multicolumn{2}{c}{$\mathrm{pH} 8.0$} \\
\cline { 2 - 7 } & Leu & Lys & Leu & Lys & Leu & Lys \\
\hline 1 a & 20.4 & 37.1 & 19.1 & 34.5 & 21.2 & 32.0 \\
1 b & 21.0 & 40.9 & 31.5 & 44.9 & 36.0 & 46.0 \\
1 c & 17.7 & 28.7 & 20.1 & 39.1 & 26.2 & 33.8 \\
1 d & - & - & 31.3 & 40.4 & - & - \\
1 e & 15.8 & 26.5 & 16.6 & 33.6 & 20.5 & 46.3 \\
1 f & 17.5 & 31.0 & 33.2 & 46.5 & 38.8 & 48.0 \\
1 g & 9.3 & 22.6 & 9.1 & 28.8 & 20.6 & 27.9 \\
1 h & 5.1 & 21.1 & 11.3 & 29.0 & 14.9 & 26.0 \\
1 i & 11.9 & 22.6 & 13.5 & 33.0 & 29.1 & 35.8 \\
1 j & 9.5 & 24.0 & 14.1 & 27.1 & 25.3 & 38.3 \\
\hline
\end{tabular}

Table 3 Decomposition percents of maleimide groups of the hetero-bifunctional cross-linkers incubated in $0.05 \mathrm{M}$ phosphate $(\mathrm{pH} 6.0,7.0$ or 8.0 ) and citrate ( $\mathrm{pH} 5.0$ ) buffers at $30^{\circ} \mathrm{C}$ for 30 minutes and also in $0.05 \mathrm{M}$ phosphate buffer, $\mathrm{pH} 7.5$, at $30^{\circ} \mathrm{C}$ for 20 minutes.

\begin{tabular}{c|r|r|r|r|r}
\hline Sample & $\mathrm{pH} 5.0$ & $\mathrm{pH} 6.0$ & $\mathrm{pH} 7.0$ & $\mathrm{pH} 8.0$ & $\mathrm{pH} \mathrm{7.5}$ \\
\hline 1 a & 3.1 & 6.2 & 21.4 & 69.0 & 18.8 \\
1 b & 2.9 & 2.5 & 7.1 & 43.8 & 9.4 \\
1 c & 3.8 & 6.6 & 32.0 & 52.0 & 37.5 \\
1 d & 3.2 & 1.5 & 18.3 & 48.7 & 29.6 \\
1 e & 17.0 & 15.2 & 26.9 & 44.0 & - \\
1 f & 3.0 & 0.7 & 2.0 & 41.0 & 8.3 \\
1 g & 22.9 & 18.7 & 41.9 & 56.1 & - \\
1 h & 5.0 & 2.4 & 6.0 & 12.2 & 8.9 \\
1 i & 4.7 & 2.0 & 6.3 & 7.5 & 8.0 \\
1 j & 5.3 & 3.0 & 4.5 & 8.4 & 5.0 \\
\hline
\end{tabular}

なエステルと安定なマレイミド基を有する。脂肪族架橋 剤は構造の差がそれほど影響せず, 安定なマレイミド基 を有する。この結果電子吸引基は活性エステルの反応性 とマレイミド基の安定性をともに減じると推定された。 そこで電子供与基を $o$-または $p$-位に有する架橋剤 $1 \mathrm{~d}$ 〜 $\mathrm{g}$ まで合成した。1 $\mathrm{f}$ は最も高い活性エステル反応性 と安定なマレイミド基を有する (表 2, 3 参照)。また MBS $1 \mathrm{~b}$ もこれに準ずる性状を有する。残念ながら $1 \mathrm{f}$ は $1 \mathrm{~b}$ に比較すると水溶性で劣っていた。

7. 4. 簡単な改良酵素標識法の開発 EIA とラジオ イムノアッセイ (RIA) を比較すると, 感度, 精度ともに 前者は遜色なく，さらに放射能による障害の恐れがない 点で優れている ${ }^{412)}$ 。しかし，蛋白質などの高分子には ${ }^{125} \mathrm{I}$ によるヨード化反応は操作が簡単なので ${ }^{87 ~ 89),}{ }^{125} \mathrm{I}$ の半减期が 60 日であり， 2 ケ月ごとに標識体を作成する 必要や，さらに放射能障害の恐れがあるにもかかわらず, 高分子蛋白の抗体や抗原の標識に最む多用されている。 従って筆者らは ${ }^{125} \mathrm{I}$ の標識法より操作が簡便な改良酵素

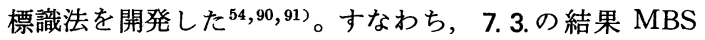
型試薬類は $0.1 \mu \mathrm{mol} / \mathrm{ml}$ の低濃度でも良好な反応性を示 すが，マレイミド基は分解しやすいので，第 1 段階のア シル化の際に試薬に対するアミノ基のモル比を 10 倍以 上にすることで反応収率を高め, 反応終了後過剩の試薬 を除く操作なしに直接第 2 反応を行って酵素標識後に 1 回のクロマトグラフィーで目的の酵素標識体が得られ る。この操作は 1 日で完了し得る。この方法は低分子の $\mathrm{VM}^{90)}$, 分子量約 1 万のネオカルチノスタチン ${ }^{91)}$ から高 
分子のヤギ抗家鬼 $\operatorname{IgG}$ 抗体 ${ }^{54)}$ の酵素標識法に応用でき た。現在, 筆者の研究室では, 初心者の特別実習生でも, 抗原や抗体の酵素標識体を1日で調製している。その結 果現在最も多用されている RIA 法の EIA 法に比する優 利な点は, 標識活性測定に自動化された $\gamma$ ーシンチレーター が使用できる点が唯一の利点であると筆者は考えてい る。

\section{5. 医薬品の新しい抗原作製法 酵素標識法とと} もに重要な蛋白修飾法の応用は薬物の抗原作製法である。 低分子の薬物はハプテンに属し，それ自体では抗原性を 持たず，蛋白との複合体に誘導して始めて抗原性が得ら れる ${ }^{5,6,28)}$ 。簡単な構造の薬物の抗原作製法は 4. 節で述 べた方法が適用できるが, 少し複雑な構造の薬物には 5. 節で述べた非選択的な方法で調製されたので，この場合 には千倍以上に希釈しても免疫測定法に使用できる良好 な抗血清を得ることは容易でなかった。筆者らもVM の 抗血清作製研究 ${ }^{23)}$ でこのことを痛感したので, MBS 型 架橋剂を利用する 3 段階の反応を行なう新しい薬剂の抗 原作製法を開発した ${ }^{15 ~ 17) 。 ~}$

第 1 反応: MBS 型架橋剤によるハプテンのアミノ基 ヘのマレイミド基導入 (酵素標識法の第 1 反応と同じ)。

第 2 反応: 蛋白質へのチオール基導入（ジスルフィド 結合のチオール交換反応, 還元反応, あるいはアミノ基 にチオール基を導入する方法が利用可能； 5. 2.節参照)。

第 3 反応 : 第 1 反応で得たマレイミド導入ハプテンと 第 2 反応で得たチオール導入蛋白を混合するだけのハプ テン一蛋白複合反応。

この新方法を開発した結果, それまで作製が困難であ った種々の薬剤, ペニシリン ${ }^{70,92,93)}$ 。セファロスポリン 94), $\mathrm{VM}^{90,92)}$, ブラストサイジン $\mathrm{S}^{71)}$, カナマイシン ${ }^{95)}$, トブラマイシン ${ }^{96)}$, ゲンタマイシン ${ }^{92)}$, ダウノマイシン

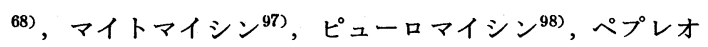
マイシン ${ }^{99)}$, スペルミン100), ブレオマイシン ${ }^{101)}$ ，その 他（投稿準備中）の薬剤に対する良好な特異抗血清が得 られ, それぞれの高感度な EIA が開発されたが,この 場合全ての抗血清は 1 万倍以上の希釈溶液が使用されて いる。

7.6. ガンミサイル療法の研究 抗腫瘍剂や放射元 素は腫瘍細胞に特異的に作用しないので, このような細 胞毒を選択的にガン治療に用いようとする研究が盛んに なってきた ${ }^{102 \sim 106)}$ 。ガン細胞にのみ存在して正常な組織 に存在が認められない抗原 ${ }^{107 ~ 108)}$ に対する特異抗体に細 胞毒物質を結合して腫瘍細胞まで運ばせて, 腫瘍細胞を 殺そうとする考え方である。放射標識特異抗体が腫瘍細 胞に集まることは Pressman ら ${ }^{109)} に よ り$ 初めて観察され，
これを利用してがんの局在場所診断の試みとして, 放射 標識ポリクロナル抗体 ${ }^{110 ~ 112)} や$ 最近ではモノクロナル抗 体 $\left.{ }^{113}, 114\right)$ を用いる研究で, 抗体のガン局所集合性も証明 されている。抗体に毒性物質を結合する方法は 5. 節と 6. 節で紹介した方法が主として用いられていて, クロラム ブシル ${ }^{115,116)}$ ，ダウノマイシン ${ }^{117) ， ホ ス ホ リ ハ ゚ ー セ ゙ ~} \mathrm{C}^{118)}$, や最近では -S-S- 結合による選択的な架橋剤(後述)を 用いて, ジフテリア毒素 ${ }^{119,120)}$ やヒマ毒素リシン ${ }^{121}$, 122)の 有毒フラグメントを抗体に結合している。これらの有毒 物質複合体を用いた治療効果については種々の問題点は あるが ${ }^{123)} こ の$ 分野の研究の一層の発展が期待される。

7. 7. 異反応性 2 価試薬に関する最近の研究 MBS 出現後, 種々の異反応性 2 価試薬が広く各国で研究され, 種々の構造の試薬類が市販されるようになった。いずれ もアミノ基とチオール基を利用する方法で, 試薬類の基 本構造は MBS 型と SPDP 型に分類される。<smiles>O=C(ON1C(=O)C=CC1=O)ON1C(=O)CCC1=O</smiles><smiles>[R]SS[R]C(=O)ON1C(=O)CCC1=O</smiles>

MBS 型試薬には $\mathrm{MBS}^{79}$ ) (Pierce 社, Rockford; 和光 純薬), $\mathrm{GMBS}^{91)} ; \mathrm{R}=-\left(\mathrm{CH}_{2}\right)_{3}-$, (同仁化学) : $\mathrm{EMCS}$ 124) $\mathrm{R}=-\left(\mathrm{CH}_{2}\right)_{4}-$, (同仁化学): $\mathrm{CHM}^{125)}$;

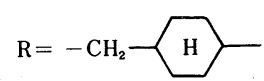

[ジーベンケミカル(株)]などが市販されている。

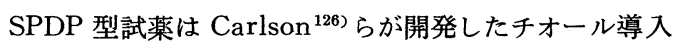
試薬である $\left(\mathrm{R}^{\prime}=\mathrm{N}_{\mathrm{N}}\right)$ 。チオール基の特殊性 を応用して, 選択性には少し問題あるが, 以下の反応で 蛋白質間の複合反応に応用できる。

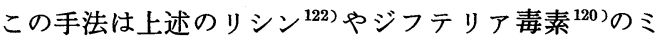
サイル療法に応用されている。

最近石川らはチオール基を導入した抗体に MBS 型試 薬 CHM でマレイミド基を導入したパーオキシダーゼ ${ }^{127)}$ やグルコースオキシダーゼ ${ }^{125)}$ で標識した EIA を報告し た。

\section{おわりに}

当初は放射標識法の代用にと研究された酵素標識法の 研究過程で発展した, 選択的な蛋白質の修飾法が開発さ れた結果，2つの生理機能を有する蛋白複合体が比較的 容易に得られるようになった。蛋白複合体は今までに なかった新しい 2 つの生理機能を兼ねそなえる特徴を持 


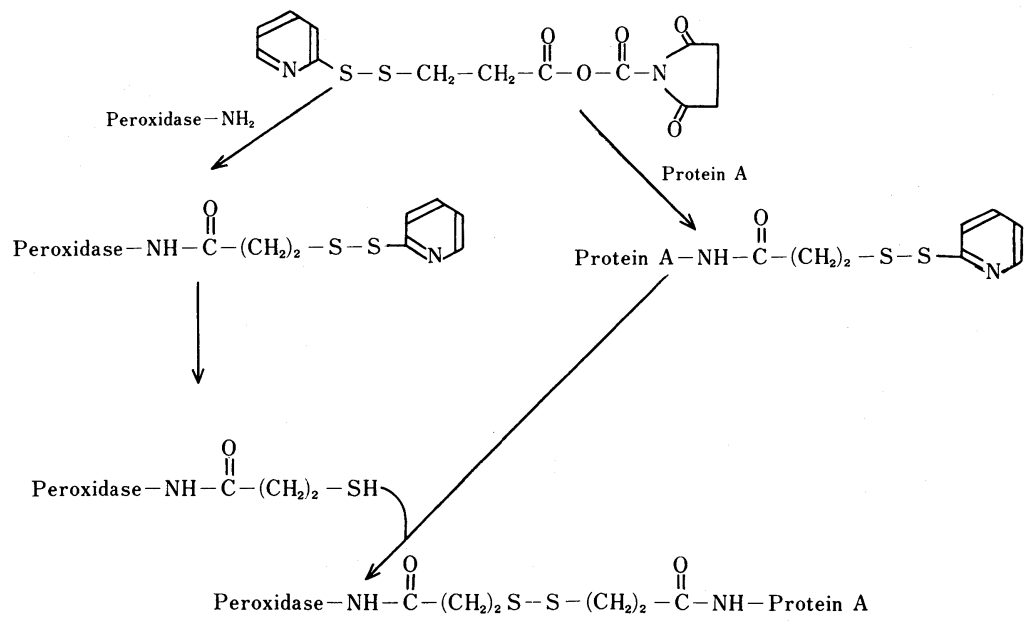

っている。この新しい複合体の特徴を生かした研究も筆 者の研究室では始めており, たとえば, 特異抗体の抗原 結合部位の高次構造が初めて解析できた研究 ${ }^{128)}$ など二, 三の新しい研究成果も得られかけているが，これらの研 究は直接修飾法とは関係がなく, 紙数の制限もあるので, 他の機会に紹介したい。

現在までの選択的な蛋白修飾研究は, 今まで述べたご とく, 主として免疫化学の分野に応用される各種の蛋白 複合体の作製が中心研究課題であった。選択的な蛋白修 飾法は単に蛋白質の修飾反応のみに適用できる方法では なく, 簡単に核酸や多糖類, リン脂質にも応用できる方 法で, さらにその方法を組み合せれば, 2 つの生理機能に 止まらず，3つあるいはそれ以上のマルチ機能を有する 複合体の作製にも使用可能な方法であると筆者は考えて いる。このような研究はまだ報告されていないが，今後 マルチ機能を持った複合体が細胞生理学の新しい分野の 扉を開くのではないかと夢みている。

最後に紹介した筆者らの研究に関し, 酵素標識法の開 発研究は長崎大・医・相川教授 (生理) との協同研究に よるものである。またアンジオテンシン I, 相川教授, 橋場教授 (同医・三内) ; インスリン相川教授・土屋教 授 (同医 -二外) ; $\mathrm{HCG}$, 同薬 - 菊谷教授, 石黒助教授 (生化), 山辺教授 (同医・産婦) ; ブラジキニン, 北里 大・医・鹿取教授 (薬理) ; トブラマイシン, 富山医薬 大・矢野教授 (一内) ; 各種抗ガン剤, 長崎大・薬・藤 原助教授（微生）の各研究は各先生とその教室の方々が 中心となって研究を進展されたものである。そのほか, 長崎大医・原教授 (二内), 市村教授 (原研内科), 奈良 医大・小西教授 (腫痬病理); 大日本製薬西村研究所長 の諸先生方のご教示ご協力を得た。また種々のご配慮を
たまわりました大阪大山村学長, 微化研梅沢研究所長に 感謝いたします。

（昭和 59 年 1 月 9 日受理）

文献

1) J. H. Kennedy, L. J. Kricka, P. Wilding, Clin. Chim. Acta, 70, 1 (1976)

2) F. Wold, in "Methods in Enzymology", (C.H.W.Hirs, S. N. Timasheff, eds.) Academic Press, New York, 25, 623 (1972)

3) O. R. Zaborsky, Immobilized Enzymes, CRC Press, Cleveland, Ohio (1973)

4) J.L. Langone, H. Van Vunakis eds., Methods in Enzymology, Vol.73, Academic Press, New York (1981)

5) V.P. Butler, Jr., Pharmacol. Rev., 29, 103 (1978)

6) B. F. Erlanger, ibid., 25, 271 (1973)

7）北川常廣, ファルマシア, 19, 781 (1983); 北川 常廣, 免疫学 (大沢利昭, 小山次郎編) 南江堂 p. 127 (1984)

8) M.J. O'Sullivan, V. Marks, in Methods in Enzymology (S.P. Colowick, and N. O. Kaplan, eds.), Academic Press, New York, 73, 147 (1981)

9) E. Ishikawa, T. Kawai, K. Miyai, eds., Enzyme Immunoassay. Igaku-Shoin, Tokyo (1981)

10) S. B. Pal, ed. Enzyme Labelled Immunoassay of Hormones and Drugs, Walter de Gruyter and Co., Berlin (1978)

11) 山本 格, 有合化, 38, 151 (1980)

12）石川栄二, 河合 忠, 宮井 潔編, 酵素免疫測定 法, 医学書院 (1982)

13）崎山文雄, 石井信一, 谷沢和隆, 笠井献一, 金岡 
祐一, 横沢英良, 生化学実験講座 1 , タンパク質 の化学IV, p. 3 (1977)

14）石井信一, 吉田信男, タンパク質化学 3 , 共立出 版, p. 1 (1973)

15) T. Kitagawa, in "Enzyme Immunoassay", (E. Ishikawa, T. Kawai, K. Miyai, eds.) Igakushoin, Tokyo-New York, pp. 136 (1981)

16）北川常廣, 臨床病理, 30, 377 (1982)

17) 北川常廣, 藤原邦雄, 谷森英明, 免疫実験操作法, 免疫学会 11，3529（1982）

18）矢島治明, 生化学実験講座 1 , タンパク質の化学 IV, p. 207 (1977)

19) Th. Wieland, W. Kern, R. Sehring, Ann. Chem., 569, 117 (1950)

20) N.F. Albertson, "Organic Reaction", John Wiley and Sons, New York, 12, 157 (1962)

21) B. F. Erlanger, S. M. Beiser, J. Biol. Chem., 228, 713 (1957)

22) B. F. Erlanger, G. Borek, S.M. Beiser, S. Lieberman, ibid., 234, 1090 (1959)

23) T. Kitagawa, T.Fujitake, H. Taniyama, T. Aikawa, J. Biochem., 83, 1493 (1978)

24) G. W. Anderson, J.E. Zimmerman, F. Callahan, J. Am. Chem. Soc., 85, 3039 (1964)

25) T.Kitagawa, T. Miura, H. Taniyama, Chem. Pharm. Bull., 20, 2176 (1972)

26) T.Kitagawa, T. Miura, M. Takaishi, H. Taniyama, Chem. Pharm. Bul., 23, 2123 (1975)

27) H.Hosoda, Y.Sakai, H. Yoshida, S. Miyairi, K. Ishii, T. Nambara, ibid., 27, 742 (1979)

28) K. Landsteiner, The Specificity of Serological Reactions, Harvard Univ. Press. Cambridge, Mass., (1945)

29) R. M. Hamburger, Science, 152, 203 (1966)

30) I. H.Silman, E. Katshalski, Ann. Rev. Riochem., 35, 373 (1966)

31) B.P.Surinov, S. E. Manoylov, Biochemistry (Engl. Transl. Biokhimiya), 31, 387 (1967)

32) T.Kitagawa, T.Shimozono, T. Aikawa, T. Yoshida, H. Nishimura, Chem. Pharm. Bull., 29, 1130 (1981)

33) H. Fasold, U. Groschel-Stewart, F. Turba, Biochem. Z., 339, 487 (1964)

34) C. B. Hiremath, R. A. Day, J. Am. Chem. Soc., 86, 5027 (1964)

35) H. Ozawa, J. Biochem., 62, 531 (1967)

36) H.Zahn, H. Zuber, Chem. Ber., 86, 172 (1953)

37) H.Zahn, H.Stuerle, Biochem. Z., 331, 29 (1958)

38) G. Kay, E. M. Crook, Nature, 216, 514 (1967)

39) R. J.H.Wilson, G. Kay, M. D. Lilly, Biochem. J., 108, 845 (1968)

40) A. Ueno, S. Oh-ishi, T.Kitagawa, M. Katori,
Biochem. Pharmacol., 12, 1659 (1981)

41) T. L. Goodfriend, L. Leviene, G. D. Fasman, Science, 144, 1344 (1964)

42) H. Zahn, F.Schade, Chem. Ber, , 96, 1747 (1963)

43) H.Zahn, F. Schade, E. Siepmann, Angew. Chem., 75, 377 (1963)

44) D. J. Herzig, A. W. Rees, R. A. Day, Biopolymers, 2, 349 (1964)

45) F. M.Richards, J. R. Knowles, J. Mol. Biol., 37, 231 (1968)

46) B. R. Brooks, O. L. Klamerth, Eur. J. Biochem., 5, 178 (1968)

47) F. A. Quiocho, F. M.Richards, Pro. Natl. Acad. Sci. U. S., 52, 833 (1964)

48) G. N. Reeke, J. A. Hartsuck, M. L. Ludwig, F. A. Quiocho, T. A. Steitz, W. P. Lipscomb, ibid., 58, 2220 (1967)

49) P.D. Weston, S. Avrameas, Biochem. Biophys. Res. Commun., 45, 1574 (1971)

50) S. Avrameas, Immunochemistry, 6, 43 (1969)

51) S. Avrameas, T. Ternynck, ibid., 8, 1175 (1971)

52) T. J. Greenwalt, E. McF. Swierk, E. A. Steane, J. Immunol. Methods, 8, 351 (1975)

53) R. M. Hendry, J.E.Herrmann, ibid., 35, 285 (1981)

54) H. Tanimori, F. Ishikawa, T.Kitagawa, ibid., 62, 123 (1983)

55) N.H.Alexander, Anal. Chem., 30, 1292 (1958)

56) E. Roberts, G. Rouser, ibid., 30, 1291 (1958)

57) J.E. Moore, W.H.Ward, J. Am. Chem. Soc., 78, 2414 (1956)

58) D. G. Smyth, A. Nagamatsu, J. S. Fruton, ibid., 82, 4600 (1960)

59) P.Kovacic, R. W. Hein, ibid., 81, 1187 (1959)

60) H. Zahn, L. Lumper, Hoppe-Seyler's, $Z$. Physiol. Chem., 349, 485 (1968)

61) P. O. Tawney, R. H.Scyder, R.P. Conger, K. A. Lubbrand, C. H. Stiteler, A.W. Williams, J. Org. Chem., 26, 15 (1961)

62) W. B. Freedberg, J.K. Hardman, J. Biol. Chem., 246, 1439 (1971)

63）松本 博, 国則登代, 生物化学実験法 10, 学会出版センター (1978)

64) 石黒正恒, 生物化学実験法 8, 学会出版センター (1978)

65) J.Carlson, R. Axen, T. Unge, Eur. J. Biochem., 59, 567 (1975)

66) I. M.Klotz, R.E.Heiney, Arch. Biochem. Biophys., 96, 605 (1962)

67) K. Kato, Y. Hamaguchi, H. Fukui, E. Ishikawa, J. Biochem., 78, 235 (1975) 
68) K. Fujiwara, M. Yasuno, T. Kitagawa, J. Immunol. Methods, 45, 195 (1981)

69) G.L.Ellman, Arch. Biochem. Biophys., 82, 70 (1959)

70) T. Kitagawa, T. Kanamaru, H. Wakamatsu, H. Kato, S. Yano, Y. Asanuma, J. Biochem., 84, 491 (1978)

71) T.Kitagawa, T.Kawasaki, H. Munechika, ibid., 92, 585 (1982)

72) K. Kato, H. Fukui, Y. Hamaguchi, E. Ishikawa, J. Immunol., 116, 1554 (1976)

73) J.Porath, in Methods in Enzymology, (W. B. Jakoby and M. Wilchek eds.) Academic Press, New York (1974)

74) T.Kristiansen, L. Sundberg, J. Porath, Biochim. Biophys. Acta, 184, 93 (1969)

75) A. Kawaoi, P. K. Nakane, Fed. Proc., 32, 840 (1973)

76) P.K. Nakane, in Methods in Enzymology, Academic Press, New York, Vol. 37, 133 (1975)

77) D. M. Weir ed., Handbook of Experimental Immunology, 3rd Ed. Blackwell Scientific Publications, Oxford (1978)

78) A. Kawamura, Jr. ed., Fluorescence antibody techiques and their applications, 2nd ed. Univ. Tokyo Press (1977)

79) T.Kitagawa, T. Aikawa, J. Biochem., 79, 233 (1976)

80) T. Kitagawa, T. Miura, K. Fujiwara, H. Taniyama, Chem. Pharm. Bull., 20, 2215 (1972)

81) T. Kitagawa, T.Miura, C. Takaishi, H. Taniyama, ibid., 24, 1324 (1976)

82）北川常廣, 武部勝海, 江藤省三, 伊藤俊哉, 土屋 涼一, 相川忠臣, 臨床化学, 6, 178 (1978)

83) T.Aikawa, S.Suzuki, M.Murayama, K. Hashiba, T. Kitagawa, E. Ishikawa, Endocrinology, 150, 1 (1979)

84) M. Kikutani, M. Ishiguro, T. Kitagawa, S. Imamura, S. Miura, J. Clin. Endocrinol. Metab., 47, 980 (1978)

85) M. J. O'Sullivan, E. Gnemmi, D. Morris, G. Chieregatti, M.Simmons, J. W. Bridges, V. Mark, FEBS Lett., 95, 311 (1978)

86) T.Kitagawa, T.Shimozono, T. Aikawa, H. Nishimura, in Peptide Chemistry (T. Nakajima, ed.), Protein Research Foundation, Osaka, pp. 21 (1976)

87）入江 實編, 続ラジオイムノアッセイ, 講談社 (1979)

88) T. Chard, An Introduction to Radioimmunoassay and Related Techiques, North Holland Publ., Amsterdam, (1978)

89) E. T. John, M. H.William, in Methods in
Enzymology, (J. J. Langone, H. Van Vunakis eds.) Academic Press, 73, 79 (1981)

90) T. Kitagawa, H. Tanimori, K. Yoshida, H. Asada, T.Miura, K. Fujiwara, Chem. Pharm. Bull., 30, 2487 (1982)

91) H. Tanimori, T. Kitagawa, T. Tsunoda, R. Tsuchiya, J. Pharm. Dyn., 4, 812 (1981)

92) T.Kitagawa, T.Kanamaru, H. Kato, S. Yano, Y. Asanuma, in Enzyme Labelled Immunoassay of Hormones and Drugs, (S. B. Pal.ed.) pp. 59, Walter de Gruyter and Co., Berlin New York (1978)

93) T. Miura, H. Kouno, T. Kitagawa, J. Pharm. Dyn., 4, 706 (1981)

94）大谷 渡, 木ノ上千保子, 藤原邦雄, 北川常廣, 日本薬学会第 102 年会発表 (1982)

95) T. Kitagawa, K. Fujiwara, S. Tomonoh, K. Takahashi, M. Koida, J. Biochem., 94, 1165 (1983)

96) H. Suzuki, H. Kato, N. Nakano, S. Yano, T. Kitagawa, J. Antibiotics, 34, 1195 (1981)

97) K. Fujiwara, H. Saigusa, M. Yasuno, T. Kitagawa, Cancer Res., 42, 1487 (1982)

98) K. Fujiwara, A. Ogawa, H. Asada, H. Saikusa, H. Nakamura, S. Ono, T. Kitagawa, J. Biochem., 92, 1599 (1982)

99) K. Fujiwara, M. Yasuno, T. Kitagawa, Cancer Res., 41, 4121 (1981)

100) K. Fujiwara, H. Asada, T. Kitagawa, K. Yamamoto, T. Ito, R. Tsuchiya, M. Sohda, N. Nakamura, K. Hara, Y. Tomonaga, M. Ichimaru, S. Takahashi, J. Immunol. Methods, 61, 217 (1983)

101) K. Fujiwara, M. Isobe, H. Saikusa, H. Nakamura, T.Kitagawa, S. Takahashi, Cancer Treatment Reports, 67, 363 (1983)

102) T.Ghose, A. Biair, J. Natl. Cancer Inst., 61, 657 (1978)

103) R. D. Ruebns, Lancet, 1, 498 (1974)

104) G.Gregoriadis, Nature, 265, 407 (1977)

105) M.Szewerle, K.S. Driscoli, Eur. J. Cancer, 13, 529 (1977)

106) J.H. Fendler, A. Romero, Life Sci., 20, 1109 (1977)

107) D. W. Weiss, Cancer Immunol. Immunother., 2, 11 (1977)

108) G. Klein, E. Klein, Proc. Natl. Acad. Sci. U.S.A., 74, 2121 (1977)

109) D.Pressman, R.Pressman, Int.. J. Appl. Radiat. Isot., 18, 617 (1965)

110) M.S. Mahaley, Jr., J. L. Mahaley, E.D. Day, Cancer Res., 25, 779 (1965)

111) T.Koji, N. Ishii, T. Munehisa, S. Nakamura, A. Tamenishi, A.Hara, K. Kobayashi, Y. Tsukada, H. Hirai, Cancer Res., 40, 3013 
(1980)

112) D. M. Goldenberg, E.E. Kim, F.H. Deland, Proc. Natl. Acad. Sci., 78, 7754 (1981)

113) D. Colcher, M. Zalvtsky, W. Kaplan, D. Kufe, F. Austin, J.Schlom, Cancer Res., 43, 736 (1983)

114) A. E. Frankel, R. V. Rouse, M. C. Wang, /T. M. Chu, L. A. Herzenberg, ibid., 42, 3714 (1982)

115) T. Ghose, S. P. Niganm, Cancer, 29, 1398 (1972)

116) I. Fleghner, Eur. J. Cancer, 9, 741 (1972)

117) E. Hurwitz, R. Maron, M.Sela, Cancer Biochem. Biophys., 1, 197 (1976)

118) R. A. Rlickinger, S. R. Trost, Eur. J. Cancer, 12, 159 (1976)

119) F. L. Moolten, S. R. Cooperband, Science, 169, 68 (1970)

120) T.E. Bumol, Q.C. Wang, R. A. Reisfeld, N. O.
Kaplan, Proc. Natl. Acad. Sci. U.S. A., 80, 529 (1983)

121) L. L.Houston, R. C. Nowinski, Cancer Res., 41, 3913 (1981)

122) D. M. Neville, Jr., R. Youle, Immunol. Rev., 62, 75 (1982)

123）岩城裕一，菊地浩吉，免疫，20，1537（1983）

124) O. Keller, J. Rudinger, Helv. Chim. Acta, 58, 531 (1975)

125) S. Yoshitake, Y. Yamada, E. Ishikawa, R. Masseyeff, Eur. J. Biochem., 101, 395 (1979)

126) J.Carlsson, H.Drevin, R. Axen, Biochem. J., 173, 723 (1978)

127) S. Yoshitake, M. Imagawa, E. Ishikawa, Anal. Lett., 15 (B2), 147 (1982)

128) T. Kitagawa, H. Tanimori, K. Yoshida, T. Miura, K. Fujiwara, J. Biochem., 91, 1601 (1982)

\section{「高分解能 $\mathbf{N M R}$}

$\mathrm{NMR}$ スペクトル程化学に大きなインパクトを与えた 技術はない。NMR 装置はその後も進歩を続け, ${ }^{13} \mathrm{C} N M R$ や, 核オーバーハウザー効果の他, パルスフーリエ変換 法などの急速な発達を遂げた。これらの新技術は超伝導 磁石の開発にささえられて大変めざましい利用価値を示 した。

本書はこれらの新技術を基本装置と基本理論を基礎に して解説した, "High Resolution NMR-Theory and Chemical Applications" Second Edition の邦訳であ って，1）歴史的背景，2）理論，3）装置および測定 技術，4）化学シフト，5) 電子スピンースピン相互作 用，6）構造決定への利用，7）複雑なスペクトルの解 析，8）緩和，9）二重共鳴法，11）パルスフーリエ 変換法, 11) 変換過程 : 動的 NMR, 12）溶媒効果と 水素結合，13）定量分析への NMR の利用，14）最近 の進歩, よりなる。構造解析を志す学生諸君に大変便利 なテキストであろう。章末には練習問題が付けられ，こ

\author{
E.D.Becker 著東京化学同人 \\ 斉藤 肇・神藤平三郎 訳 3,800 円
}

れは巻末にまとめられた末知のプロトン NMR スペクト ルに対応している。このプロトン NMR スペクトルには

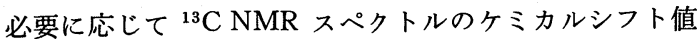
が与えられていて総合的解析に便利である。一応解析力 を身につけた初心者には,特にこの 40 種のスペクトル解 読を推める。不明の点があったら再び本文に戻って理解 するよう心掛ければ，本書の NMR テキストとしての価 值をより一層高めると信ずる。

更に，本書の訳者らの専門分野である二次元 NMR と 固体高分解能 NMR について訳者補遺がつけられている。 この部分は原著にないものであるが，最近の NMR の最 先端を知るのに大変便利で, 本書の価值を高めるのに役 立っている。

これから NMR を勉強しようとする学生諸君や，もう 一度知識の整理を心掛ける研究者に最高のテキストとな るであろう。

（小倉治夫） 